\title{
Cefoxitin Sodium
}

National Cancer Institute

\section{Source}

National Cancer Institute. Cefoxitin Sodium. NCI Thesaurus. Code C28915.

The sodium salt form of cefoxitin, a beta-lactam, second-generation cephalosporin antibiotic with bactericidal activity. Cefoxitin sodium binds to and inactivates penicillinbinding proteins (PBP) located on the inner membrane of the bacterial cell wall. PBPs participate in the terminal stages of assembling the bacterial cell wall, and in reshaping the cell wall during cell division. Inactivation of PBPs interferes with the cross-linkage of peptidoglycan chains necessary for bacterial cell wall streng th and rigidity. This results in the weakening of the bacterial cell wall and causes cell lysis. 